\title{
Estimation of acidifying deposition in Europe due to international shipping emissions in the North Sea and the North East Atlantic Ocean
}

S.G. Tsyro \& E. Berge

Research and Development Department, Norwegian

Meteorological Institute, P.O.Box 43, Blindern, N-0313 Oslo, Norway

Email: svetlana.tsyro@dnmi.no

\section{Abstract}

The contribution of sulphur $\left(\mathrm{SO}_{2}\right)$ and nitrogen oxides $\left(\mathrm{NO}_{\mathrm{x}}\right)$ emissions from international shipping in the North Sea and the north-eastern (NE) Atlantic Ocean to acidifying deposition across Europe is evaluated for 1990, 1995 and 2010 with the EMEP (European Monitoring and Evaluation Programme) two-dimensional trajectory model. A new ships emission data set for the North Sea and the NE Atlantic Ocean is implemented based on information from the Lloyd's Register of Shipping. The new emissions of $\mathrm{SO}_{2}$ and $\mathrm{NO}_{\mathrm{x}}$ are a factor of 2.2-2.8 larger then the earlier estimates used. Therefore, the presented calculations give considerably higher ships' contribution to acidification in Europe. Ship emissions from the North Sea and the NE Atlantic Ocean in 1990 exceeded $100-150 \mathrm{mg} \mathrm{m}^{-2}$ $\mathrm{a}^{-1}$ and accounted for more than $10-15 \%$ of the total acidifying deposition in many coastal areas. That is comparable with the contributions of large industrial countries.

The considerable decrease of the total European emissions of $\mathrm{SO}_{2}$ and $\mathrm{NO}_{\mathrm{x}}$ by $26 \%$ and $15 \%$ respectively between 1990 and 1995 was mainly due to the reduction of land-based emissions, whilst ship emissions are thought to remain comparatively stable. Consequently, a relative increase of importance of international shipping to acidification is registered. Our estimates also suggest that the importance of ship emissions in the North Sea and the NE Atlantic Ocean will increase in 2010 providing that European countries have reduced their national emissions according to the current reduction plans and no abatement measures with respect to international shipping are taken. 


\section{Introduction}

A number of recent estimates (e.g. Streets, Carmichael \& Arndt, 1997, Corbett \& Fischbeck, 1997) shows that ship traffic presents a significant source of sulphur dioxide and nitrogen oxides on a global scale. Ship emissions contribute to acidification of soils and fresh waters hundreds kilometres inland. An attempt to combat this problem by approving the global emission limits was made by the International Maritime organisation in 1997. An initiative was also taken to establish a $\mathrm{SO}_{\mathrm{x}}$ emission control area for the Baltic Sea and the North Sea (The North Sea Ministerial Conference, 1995).

Through the work of the EMEP under the Convention on Long Range Transboundary Air Pollution (LRTAP), transport and deposition of transboundary acidifying species has been calculated since 1985 . Emissions from international shipping were first introduced in model calculations in 1990 and derived from Bremnes (1990). A new ships emission data set for the NE Atlantic Ocean and the North Sea have been made available to the Meteorological Synthesizing Centre-West (MSC-W) for EMEP from the Lloyd's Register of Shipping in 1996 (Lloyd's Register of Shipping, 1995). The year 1990 was chosen as a base year for emission estimate, as this year was considered to be a 'typical year' with respect to shipping movement. The obtained estimates of $\mathrm{SO}_{2}$ and $\mathrm{NO}_{\mathrm{x}}$ ships emissions for this area appeared considerably higher than the previous estimates used by EMEP.

The new ship emission data aggregated to the EMEP 150x150 km grid gives a total sulphur emission of 1080 ktonnes as $\mathrm{SO}_{2}$ and a total nitrogen emission of 1550 ktonnes as $\mathrm{NO}_{\mathrm{x}}$ in 1990. In earlier EMEP calculations emission figures of 490 and 541 ktonnes respectively were used (Barrett and Berge, 1996). The evidence of a factor of 2.2-2.8 larger emissions than previously assumed asked for a renewed assessment of acidifying effects of the ship emissions in Europe. The purpose of this work is, thus, to present the updated calculations on long range transport of air pollution from international shipping in the North Sea and in the NE Atlantic Ocean.

In the present paper, firstly, we analyse the modelled depositions of sulphur and nitrogen originating from the ship emissions in 1990. Furthermore, the total European emissions of $\mathrm{SO}_{2}$ and $\mathrm{NO}_{\mathrm{x}}$ declined markedly from 1990 to 1995 by approximately $26 \%$ and $15 \%$ respectively largely due to the reduction of landbased emissions. The relative importance of international shipping was, therefore, expected to increase assuming comparatively stable ship emissions. In order to study this, 


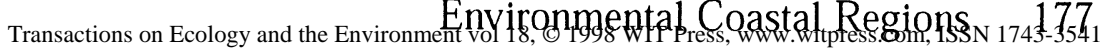

contribution of the ship emissions to the total deposition in Europe in 1995 was estimated. Finally, a scenario calculation for the year 2010 is presented.

\section{Data description}

\subsection{The dispersion model}

The calculations presented in this paper were carried out with use of the EMEP/MSC-W routine acid deposition model (Eliassen \& Saltbones, 1983; Barrett \& Berge, 1996). The model is one-layer, receptor-oriented Lagrangian with $150 \mathrm{~km}$ spatial resolution. It employs official estimates of $\mathrm{SO}_{2}, \mathrm{NO}_{\mathrm{x}}$ and $\mathrm{NH}_{3}$ national emissions and real-time meteorological data derived from the Numerical Weather Prediction model of the Norwegian meteorological Institute or analysed from observations. 4-day backward trajectories are calculated every 6 hours. Mass balance equations for chemical concentrations within air parcels following the motions in the Atmospheric Boundary Layer include emissions, chemical processes, dry and wet deposition. Exchange with the free troposphere is parameterised.

\subsection{Ship emissions in the North Sea and the NE Atlantic Ocean}

Spatial distribution of the annual international shipping emissions of $\mathrm{SO}_{2}$ and $\mathrm{NO}_{\mathrm{x}}$ in the North Sea and the NE Atlantic Ocean (not included here) shows highest emissions of the both compounds in the regions of heavy shipping activity in the southern North Sea, the English Channel, the western part of the Biscay, and in the Strait of Gibraltar.

The $\mathrm{SO}_{2}$ and $\mathrm{NO}_{\mathrm{x}}$ emissions adopted in the calculations are given in Table 1.

Table 1: Total emissions from international shipping in the North Sea and the NE Atlantic Ocean in the EMEP $150 \mathrm{~km}$ grid in 1990 (ktonnes).

\begin{tabular}{|l|c|c|}
\hline & $\mathrm{SO}_{2}$ & $\mathrm{NO}_{2}$ \\
\hline the NE Atlantic & 641 & 911 \\
\hline the North Sea & 439 & 639 \\
\hline Total & 1080 & 1550 \\
\hline
\end{tabular}

Emissions from ships in the NE Atlantic Ocean and the North Sea within the EMEP calculation domain constitute around $2.6 \%$ of the total $\mathrm{SO}_{2}$ and $6.5 \%$ of the total $\mathrm{NO}_{\mathrm{x}}$ emissions officially reported in Europe in 1990. Ship emissions of $\mathrm{SO}_{2}$ in the North Sea, which contains some of the 
busiest ports in the world, are 2-7 times the national emissions in 1990 of some adjacent countries, e.g. the Netherlands, Denmark, Sweden and Norway. Emissions of $\mathrm{NO}_{\mathrm{x}}$ are lower than only the national emissions of 8 main country-emitters in Europe.

If we assume that international ship emissions have not declined noticeably since 1990, then shipping in the NE Atlantic and the North Sea accounts for 3.5 and $7.5 \%$ of the total $\mathrm{SO}_{2}$ and $\mathrm{NO}_{\mathrm{x}}$ emitted in Europe in 1995. The projected further reduction of the land-based emissions will result in even larger portions of ship emissions (5.2 and $10.5 \%$ respectively) in 2010 .

\section{Contribution from ship emissions to the acidifying deposition in Europe}

This section presents the results of estimation of the contribution from the international shipping in the NE Atlantic and the North Sea to the total deposition of oxidised sulphur $\left(\mathrm{SO}_{\mathrm{x}}\right)$ and oxidised nitrogen $\left(\mathrm{NO}_{\mathrm{x}}\right)$ on land.

\subsection{Sulphur and nitrogen depositions from shipping in $\mathbf{1 9 9 0}$}

Figure 1 presents the modelled deposition field of $\mathrm{SO}_{\mathrm{x}}$ due to international shipping emissions in the NE Atlantic and the North Sea in 1990. The modelled deposition field of $\mathrm{NO}_{\mathrm{x}}$ deposition (not shown here) has a similar pattern, but the maximum depositions are noticeably lower. The fate of the emitted $\mathrm{SO}_{2}$ and $\mathrm{NO}_{\mathrm{x}}$ is determined by the meteorological and chemical conditions in the atmosphere. Shortly after emission a certain fraction of the emitted species is deposited in the vicinity of the sources as a local deposition. The remaining part of the emissions undergoes long range transport with the winds, chemical transformation, and dry and wet deposition to the surface. The largest $\mathrm{SO}_{\mathrm{x}}$ and $\mathrm{NO}_{\mathrm{x}}$ depositions coincide well with the areas of highest emissions. $\mathrm{SO}_{2}$ is, in particular, effectively deposited close to the emission source and has an enhanced dry deposition velocity over sea. Depositions of $\mathrm{SO}_{\mathrm{x}}$ in excess of $200 \mathrm{mg}(\mathrm{S}) \mathrm{m}^{-2} \mathrm{a}^{-1}$ are found on the both side of the English Channel, in the narrow coastal areas of England, Denmark, Germany, the Netherlands, Belgium, and northern France. Maximum depositions of $\mathrm{NO}_{x}$, however, do not exceed 100-150 $\operatorname{mg}(\mathrm{N}) \mathrm{m}^{-2} \mathrm{a}^{-1}$ and occur in the Netherlands and most of Belgium. The southern parts of the England, Norway and Sweden, Denmark, the northwestern parts of Germany and France, entire Belgium and Luxembourg, Denmark, Germany, the Netherlands, Belgium, and northern France. 


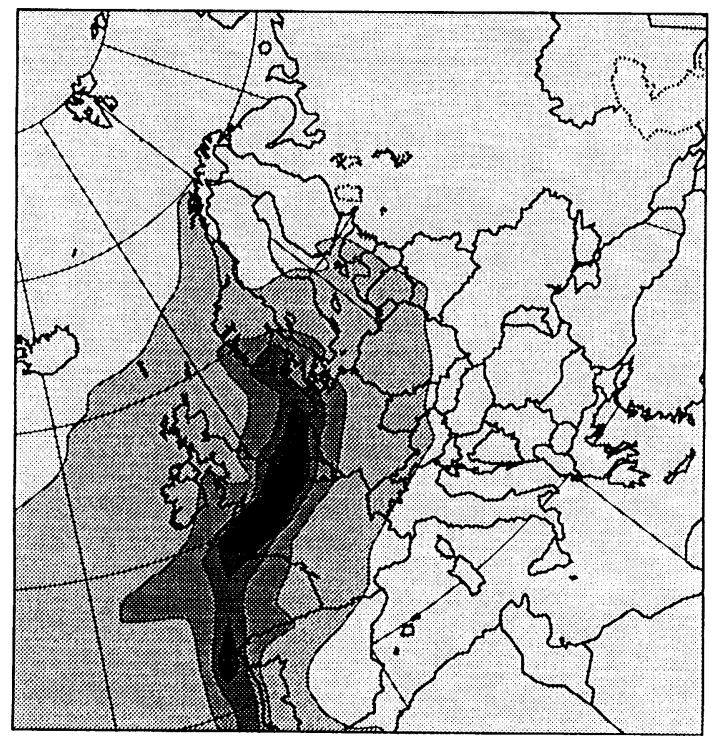

EMEP/MSC-W

units: $\mathrm{mg}(\mathrm{S}) / \mathrm{m} 2$

Figure 1: Deposition of oxidised sulphur from international shipping in the North Sea and the NE Atlantic Ocean in 1990.

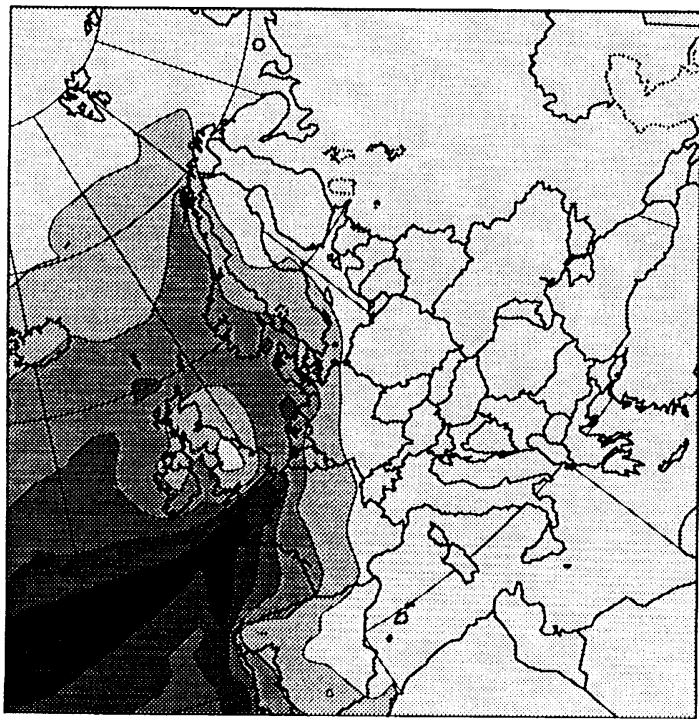

EMEP/MSC-W

Units: \%

$100-150$

$50-100$

$10-50$

Figure 2: Relative contribution of international shipping in the North Sea and the NE Atlantic to the total $\mathrm{SO}_{x}$ deposition in 1990. 
Maximum depositions of $\mathrm{NO}_{\mathrm{x}}$, however, do not exceed $100-150 \mathrm{mg}(\mathrm{N}) \mathrm{m}^{-2}$ $\mathrm{a}^{-1}$ and occur in the Netherlands and most of Belgium. Southern parts of Norway, Sweden and England, Denmark, the north-western parts of Germany and France, entire Belgium and Luxembourg, the Netherlands, and the costs of Portugal and Spain received depositions of the both components of $50-100 \mathrm{mg}(\mathrm{S} / \mathrm{N}) \mathrm{m}^{-2} \mathrm{a}^{-1}$ in 1990.

Figures 2 and 3 show the relative contribution of $\mathrm{SO}_{2}$ and $\mathrm{NO}_{\mathrm{x}}$ emissions originating from the North Sea and the NE Atlantic Ocean to the total on-land depositions in 1990. The maximum $\mathrm{SO}_{\mathrm{x}}$ contribution from ships (Figure 2 ) is above $15 \%$ and attributed to the large emissions in the English Channel. Contributions of 5 to $10 \%$ out of the total deposition is seen in quite an extensive area covering southern England and Ireland, Portugal, and a wide coastal zone from Spain to Norway.

The fraction of total anthropogenic $\mathrm{NO}_{\mathrm{x}}$ deposition due to ships is, in general, greater than that for $\mathrm{SO}_{\mathrm{x}}$ (Figure 3), with maximum contribution of $15-20 \%$ in the south of England and Ireland, and the north-west of France. Ship contributions in excess of $10 \%$ are found in this case over a considerably larger area, as $\mathrm{NO}_{\mathrm{x}}$ is rather slow deposited in its primary phase and, hence, can be transported to longer distances.

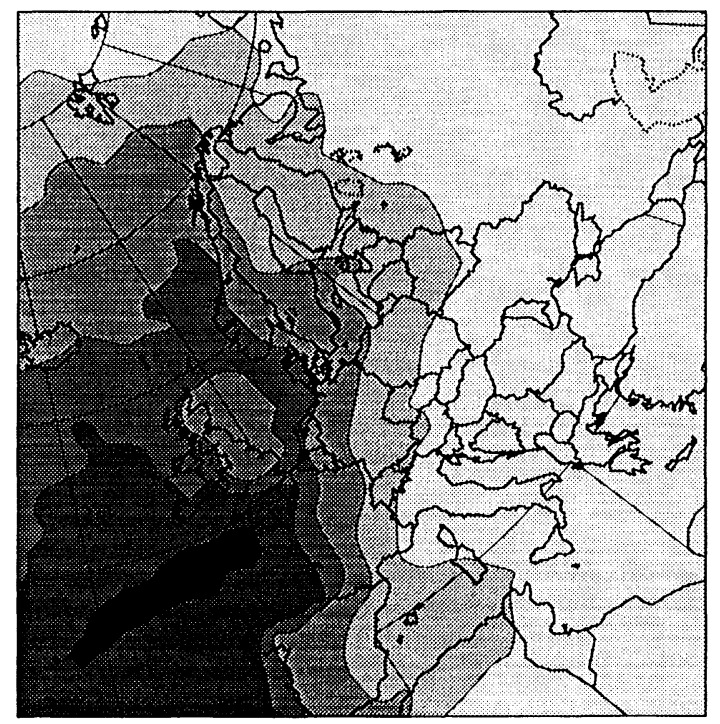

EMEP/MSC-W

Unit: \%

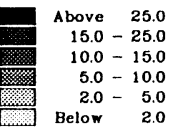

Figure 3: Relative contribution of international shipping in the North Sea and the NE Atlantic to the total $\mathrm{NO}_{\mathrm{x}}$ deposition in 1990. 
Using the ability of the Lagrangian model to allocate the modelled deposition in any receiving area to certain emission areas, it is feasible to distinguish the regions of influence of the North Sea and the NE Atlantic.

It was found that emissions of $\mathrm{SO}_{2}$ and $\mathrm{NO}_{\mathrm{x}}$ from the North Sea plays the most important role in acidifying depositions in the Netherlands (contributions of 7 and 9\% relatively), Belgium (5 and 9\%), Denmark (5 and 9\%), Norway (4 and 7\%) and England (2 and 6\%). Whilst international shipping in the NE Atlantic Ocean affects considerably Portugal, contributing with $12 \%$ to $\mathrm{SO}_{\mathrm{x}}$ and $24 \%$ to $\mathrm{NO}_{\mathrm{x}}$ depositions, Ireland (6 and 15\%), Spain ( 3 and 10\%), and England (2 and 7\%).

On the whole, a greater importance of shipping fleet to acidification in Europe than estimated by EMEP earlier is found (see e.g. EMEP/MSC-W Report 1/96, Jerre et al. (1994)). That is, even more European countries appear to be affected by ship emissions, and the relative ship contributions to acidifying depositions in the countries are found to be larger than all earlier estimates.

It should be pointed out that about $90 \%$ of the total $\mathrm{SO}_{2}$ and $\mathrm{NO}_{\mathrm{x}}$ emissions in the North Sea is found to originate from a zone of approximately 50 nautic miles from the coast line associated with the heavy traffic routes in its western and southern parts and, particularly, in the English Channel. Consequently, this zone is the dominant contributor to $\mathrm{SO}_{\mathrm{x}}$ and $\mathrm{NO}_{\mathrm{x}}$ depositions in the most environmentally sensitive areas located in Scandinavia, England, Germany and the Netherlands. Such estimates may be of a particular interest, when considering emission reduction strategies in limited, most heavily trafficked shipping areas. Besides, reducing emissions is clearly the more effective the closer intensive emission source is to sensitive areas.

\subsection{Contribution of ship traffic to $\mathrm{SO}_{\mathrm{x}}$ and $\mathrm{NO}_{\mathrm{x}}$ depositions in $\mathbf{1 9 9 5}$}

As it was discussed above, the relative role of international shipping to acidification in Europe was expected to be increasing since 1990 as a consequence of the land-based emissions reduction during this period.

A measurable increase of relative ships contribution to the total $\mathrm{SO}_{\mathrm{x}}$ and $\mathrm{NO}_{\mathrm{x}}$ deposition in many locations in 1995 is modelled. The area with relative $\mathrm{SO}_{\mathrm{x}}$ deposition of $10-15 \%$ is noticeably larger then in 1990 (not shown) and covers now broad coastal regions of France, Belgium, the Netherlands, almost entire Denmark, and southern Norway. Even more pronounced is the grown importance of the $\mathrm{NO}_{\mathrm{x}}$ ship emissions. The area of relative contributions of $10-15 \%$ has extended to include practically entire Norway and the Netherlands, considerable parts of Germany and Sweden. Portugal, Denmark and western Norway receive up to $25 \%$ of 
their $\mathrm{NO}_{\mathrm{x}}$ depositions in 1995 from ships.

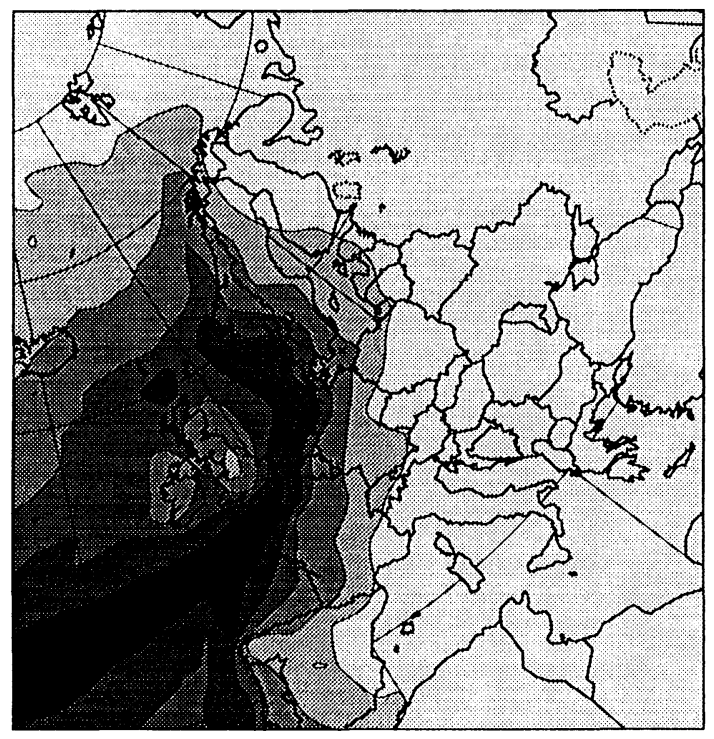

EMEP/MSC-W

Units: \%

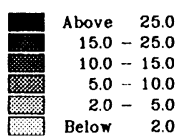

Figure 4: Relative contribution of international shipping in the North Sea and NE Atlantic to the total $\mathrm{SO}_{\mathrm{x}}$ deposition in 2010.

\subsection{Scenario calculation of acidifying deposition in Europe due to ship emissions in 2010}

An assessment of ship traffic contribution to the total $\mathrm{SO}_{\mathrm{x}}$ and $\mathrm{NO}_{\mathrm{x}}$ deposition in 2010 is made, assuming ship emissions remain unchanged at 1990 levels and projected national emissions for land-based sources after implementation of the current reduction plans. Figure 4 shows clearly that international shipping in the North Sea and the NE Atlantic could become a major cause of acidification and eutrophication in a number of European countries, accounting for $15-25 \%$ of the total $\mathrm{SO}_{\mathrm{x}}$ deposition in southern Norway, Denmark and coastal areas of Germany, the Netherlands, Belgium and France. For $\mathrm{NO}_{\mathrm{x}}$ depositions the respective area appears even larger (not shown here) and includes also Portugal and Spain. Ship contributions may reach $40 \%$ on French and English coasts in the vicinity of the English Channel, and in northern Spain (for $\mathrm{NO}_{\mathrm{x}}$ ). Table 2 illustrates the increasing relative ships impact to acid depositions in Europe unless actions to abate emissions from international shipping are taken. 
Table 2. Relative ships contribution compared with some countries to the on-land depositions in Europe ( in \%)

\begin{tabular}{|l|c|c|c|c|c|c|c|}
\hline & \multicolumn{3}{|c|}{$\mathrm{SO}_{\mathrm{x}}$} & & \multicolumn{3}{|c|}{$\mathrm{NO}_{\mathrm{r}}$} \\
\cline { 2 - 4 } \cline { 6 - 8 } country & 1990 & 1995 & 2010 & & 1990 & 1995 & 2010 \\
\hline Germany & 6 & 12 & 43 & & 23 & 36 & 38 \\
United Kingdom & 16 & 27 & 55 & & 47 & 55 & 105 \\
France & 31 & 47 & 61 & & 55 & 62 & 62 \\
Belgium & 111 & 155 & 180 & & 211 & 247 & 247 \\
Norway & 1020 & 1489 & 1531 & & 558 & 515 & 710 \\
\hline
\end{tabular}

\section{Summary and conclusions}

New data on international shipping emissions for the North Sea and the NE Atlantic Ocean from the Lloyd's Register of Shipping was employed by the EMEP/MSC-W to assess the impact of ship traffic to acidification in Europe. These data are based on a comprehensive refined methodology for quantification of ship emissions (Lloyd's Register, 1995), and, therefore, considered to be of a higher quality than earlier estimates used in the EMEP calculations. The new emissions are a factor of 2 larger for $\mathrm{SO}_{2}$ and about a factor 3 larger for $\mathrm{NO}_{\mathrm{X}}$. The EMEP Lagrangian acid deposition model was used in order to analyse the long range transport of the $\mathrm{SO}_{2}$ and $\mathrm{NO}_{\mathrm{x}}$ emissions from ships.

The calculation results and their discussion presented in this study clearly points out the importance of international shipping emissions as a source to the deposition of acidifying compounds in Europe. Oxidised sulphur and nitrogen depositions resulting from these ship emissions are estimated to exceed $10-15 \%$ and $15-20 \%$ respectively in 1990 in narrow coastal regions and are comparable with the contributions of large industrial countries. Countries exposed most to the acidifying depositions from ships in the North Sea are Belgium, Denmark, the Netherlands and Norway. The NE Atlantic is found to be a major contributor to acidifying depositions in Portugal, Ireland and Spain. The increased impact of ship emissions to the acidification in Europe in 1995 is assessed. Moreover, our estimates show the appreciable further increase of ships importance as a source of acidifying emissions in 2010 taking into consideration the current reduction plans for land-based emissions, and if no measures are taken to limit ships emissions. Their relative contribution to the acidifying deposition may exceed $20-25 \%$ (up to $40 \%$ ) in the areas effected most, including those where ecosystems are especially sensitive to acidification. 


\section{Environmental Coastal Regions}

\section{References:}

[1] Barrett, K. \& Berge, E. (eds.), Transboundary air pollution in Europe. MSC-W Status Report 1996. Part 1: Estimated dispersion of acidifying agents and of near surface ozone. EMEP/MSC-W, Report 1/96, Norwegian Meteorological Institute, Oslo, Norway, 1996.

[2] Bremnes, P.K., Calculation of exhaust gas emission from sea transport. Methodology and results. In EMEP Workshop on emissions from ships, Oslo, 7-8 June 1990 (ed.by Gabriel Kielland). State Pollution Control Authority, Oslo, pp. 60-84, 1990.

[3] Corbett, J.J. \& Fischbeck, P., Emissions from Ships, Science, 278, pp. 823-824, 1997

[4] Eliassen, A. \& Saltbones, J., Modelling of long range transport of sulphur over Europe: a two-year model run and some model experiments. Atmospheric Environment, 17, pp. 1457-1473, 1983.

[5] Jerre, J., Barrett, K. and Styve, H. (1994). The contribution from ship emissions to acidification in the North Sea countries. The North Sea as a Special Area - Phase II. Report No. 94-3437. The Norwegian Veritas Industry, Høvik, Norway.

[6] Lloyd's Register of Shipping, Marine Exhaust Emissions Research Programme. Lloyd's Register of Shipping, London, 1995.

[7] Streets, D.G., Carmichael, G.R. \& Arndt, R.L., Sulfur dioxide emissions and sulfur deposition from international shipping in Asian Waters, Atmospheric Environment, 31, pp. 1573-1582, 1997.

[8] The North Sea Ministerial Conference, Esbjerg, 1995.

[9] The Swedish NGO Secretariat on Acid Rain, The European Federation for Transport and Environment \& European Environmental Bureau, Cleaner shipping - a cheap way to reduce acidification in Europe. Visby, Sweden, 1997. 